\title{
Sustainable Multi-Objective Multi-Reservoir Optimization Considering Environmental Flow
}

\author{
Pushpak D. Dabhade, Dattatray G. Regulwar \\ Department of Civil Engineering, Government College of Engineering, Aurangabad, India \\ Email: pushpak3dabhade@gmail.com,regulwar@gmail.com
}

How to cite this paper: Dabhade, P.D. and Regulwar, D.G. (2021) Sustainable Multi-Objective Multi-Reservoir Optimization Considering Environmental Flow. Journal of Water Resource and Protection, 13, 945-956.

https://doi.org/10.4236/jwarp.2021.1312051

Received: October 24, 2021

Accepted: December 5, 2021

Published: December 8, 2021

Copyright $\odot 2021$ by author(s) and Scientific Research Publishing Inc. This work is licensed under the Creative Commons Attribution International License (CC BY 4.0).

http://creativecommons.org/licenses/by/4.0/

\begin{abstract}
Increasing demand for water from all sectors presents a challenge for policy makers to improve water allocation policies for storage reservoirs. In addition, there are many other organisms and species present in river waters that also require water for their survival. Due to the lack of awareness many times the minimum required quantity and quality of water for river ecosystem is not made available at downstream of storage reservoirs. So, a sustainable approach is required in reservoir operations to maintain the river ecosystem with environmental flow while meeting the other demands. Multi-objective, multi-reservoir operation model developed with Python programming using Fuzzy Linear Programing method incorporating environmental flow requirement of river is presented in this paper. Objective of maximization of irrigation release is considered for first run. In second run maximization of releases for hydropower generation is considered as objective. Further both objectives are fuzzified by incorporating linear membership function and solved to maximize fuzzified objective function simultaneously by maximizing satisfaction level indicator $(\lambda)$. The optimal reservoir operation policy is presented considering constraints including Irrigation release, Turbine release, Reservoir storage, Environmental flow release and hydrologic continuity. Model applied for multi-reservoir system consists of four reservoirs, i.e., Jayakwadi Stage-I Reservoir (R1), Jayakwadi Stage-II Reservoir (R2), Yeldari Reservoir (R3), Siddheshwar Reservoir (R4) in Godavari River sub-basin from Marathwada region of Maharashtra State, India.
\end{abstract}

\section{Keywords}

Optimization, Multi-Objective Analysis, Multi-Reservoir, Reservoir Operation, Environmental Flow, Linear Programming, Fuzzy Logic 


\section{Introduction}

Uncertain rainfall and the constantly increasing need for water have made it necessary to build big reservoirs on rivers and manage the water in the reservoir for different purposes.

Labadie [1] has presented a review on optimal operation model for multi-reservoir systems by all different methods of optimization for water resources operations and management. Wurbs [2] has discussed different reservoir-system simulation and optimization models to give guideline about different methods and its usefulness in various types of decision-support situations. Kim et al. [3] have developed a monthly operating rule for single-reservoir operation for Soyanggang dam basin in Korea Peninsula, with objectives of minimization of shortage and maximization of sum of hydropower production. The simulation results are obtained by using the developed piecewise-linear operating rule. Chen et al. [4] have suggested an interactive dynamic programming model for optimizing reservoir operation to support the policy makers for balancing humans and environmental water requirement. Mousavi et al. [5] have presented reservoir operation model using a dynamic programming fuzzy rule-based approach. This model was applied to the reservoirs system in Iran. Developed model gives better values of the simulated objective function with the higher reliability of meeting the demand. Nagesh Kumar et al. [6] have developed a reservoir operation model for flood control purpose with the help of folded dynamic programming. Regulwar and Anand Raj [7] have proposed a multi-reservoir operation model using genetic algorithm under fuzzy environment considering multi-objectives. Regulwar and Kamodkar [8] derived a fuzzy constrained reservoir operation model for multi-purpose reservoir. Model is useful in dealing with imprecise constraints. Yesmin and Alim [9] presented an advanced transformation technique to solve multi-objective optimization problem. Computer application of algorithm has been demonstrated by a flow chart.

Environmental Flow: Brisbane declaration [10] provides a clear idea of Environmental Flow (E-Flow) and it can be defined as "The quantity, timing, and quality of water flows required to sustain freshwater and estuarine ecosystems and the human livelihoods and wellbeing that depend on these ecosystems." This declaration was formulated in 2007 during the 10th International River Symposium and International Environmental Flows Conference held in Brisbane, Australia, with participation of delegates from more than 50 countries. Jain and Kumar [11] have highlighted Indian scenario of environmental flow assessment with different Indian River case studies. Lokgariwar et al. [12] have discussed a case study of Upper Ganga River cultural water requirements for environmental flow assessment. S.K. Jain [13] has suggested adaptive management of environmental flow, which involves estimation of environmental flow requirements, consideration of those requirements in reservoir operation policies and monitoring the results after implementation to revise the estimation.

Indian scenario: The Indian summer monsoon typically lasts from June 
September, with large areas of western and central India receiving more than $90 \%$ of their total annual precipitation during the period, and southern and northwestern India receiving $50 \%$ to $75 \%$ of their total annual rainfall. These trends increase the tendency to store more water in reservoirs during this season to make it available for remaining period of the year, which affect the availability of baseflow in river throughout the year. In most of the rivers no flow condition is observed during many days in non-monsoon season because of shortage of rainfall and the storage made by upstream reservoirs. Such situation degraded the river ecosystem badly and need a sustainable approach to make minimum flow available for all seasons.

Recommendation by Central Water Commission (CWC) [14]: To address the issue of Environmental flow in India Central Water Commission in 2007 carried out studies on minimum flows in various Indian rivers: Himalayan rivers such as the Bhagirathi, Alaknanda; and other rivers in the Krishna and Godavari basins, and southern tributaries of the Yamuna and Tapi. The studies show that, in the case of Himalayan rivers due to snow melting from different Himalayan glaciers availability of natural flows is very high. Despite this it's not possible to preserve such high availability of water at lower reaches due to high amount of water requirements.

CWC recommends environmental flow conditions for Himalayan rivers as: The minimum environmental flow must not be less than $2.5 \%$ of the $75 \%$ dependable annual flow. Also, a flushing flow with a peak flow of not less than $250 \%$ of the $75 \%$ dependable annual flow is required during the monsoon period. For other than Himalayan rivers recommendations are: The minimum environmental flow must not be less than $0.5 \%$ of the $75 \%$ dependable annual flow. Also, a flushing flow with a peak flow of not less than $600 \%$ of the $75 \%$ dependable annual flow is required during the monsoon period.

In October 2018 Central Government circulated a notification regarding minimum environmental flows requirements in Ganga [15] which has to be maintained at downstream of different projects constructed for diversion of river flows for different purposes like irrigation, hydropower, domestic and industrial and other needs. The order of e-flows applicable to the upper Ganga River basin starts from the originating glaciers to Unnao district of Uttar Pradesh. The requirement of minimum environmental flows is applicable to all the existing, under-construction and future projects. For the existing projects a period of three years is given to ensure minimum environmental flow which is unable to meet the CWC norms at present.

Government of Maharashtra Water Resources Department published a report on Integrated State Water Plan for Maharashtra [16] about importance of water for eco-system it describes river, water sources, aquifers and wetlands will be regarded as natural systems and must be protected from overuse, extinction, pollutants or pollution. In consultation with experts, stake holders and NGO essential steps shall be planed like preparation of annual action plan by incorporating necessary environment flow for restoration and maintenance of river health. 
After the brief literature study is observed that the tendency to store more water often leads to a lack of water flow in the river at downstream of the dams, and this makes very serious impacts on the biodiversity that is dependent on the river water and grows in it. While achieving the targets of human water needs environmental flow needs to maintain the river ecosystem should be taken into consideration. Thus, reservoir optimization techniques are helpful to implement optimal policy for multi-purpose reservoirs. Also, necessary environmental flow releases should be estimated and incorporated in reservoir operation to achieve a sustainable development policy in reservoir planning. In present study it is observed that availability of inflow in Godavari basin is insufficient, also no flow condition is also been observed in river during many days of year. It shows inability to satisfy both minimum required environmental flow release conditions recommended by CWC, so the condition of a flushing flow of not less than $600 \%$ of the $75 \%$ dependable annual flow is not feasible to adopt. In present model condition of $0.5 \%$ of the $75 \%$ dependable annual flow is considered as release for environmental flow and considered constant for all months. To achieve sustainable development a complex problem of deriving the optimal operational policy for multi-objective multi-reservoir system is presented in this study considering the environmental flow releases.

\section{System Description}

This study involves the operations planning of the multi-reservoir system of four reservoirs Jayakwadi Stage-I (R1) constructed across Godavari River situated at Paithan in Aurangabad district, Jayakwadi Stage-II (R2) constructed on river Sindaphana at Majalgaon in Beed district, Projects constructed on Purna River near Yeldari (R3) in Parbhani district and Siddheshwar project (R4) in Hingoli district from Maharashtra State, India. Figure 1 shows the sketch of location of

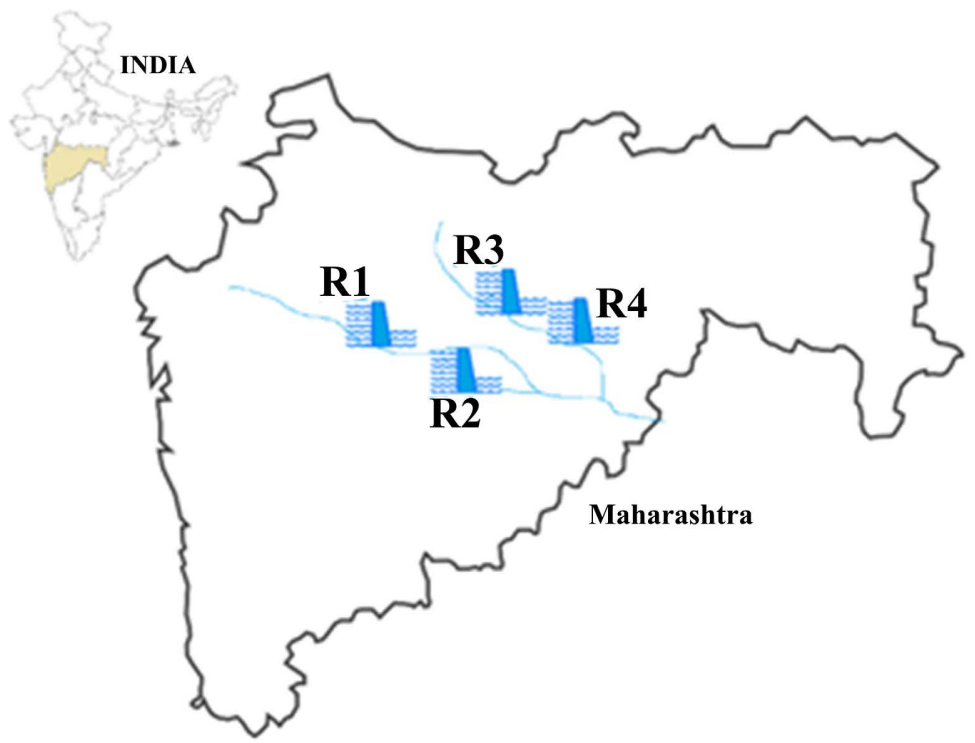

Figure 1. Sketch showing location of reservoirs. 
all reservoirs. Jayakwadi Stage-I (R1) and Jayakwadi Stage-II (R2) projects are multi-purpose reservoirs which releases water for different demands like Irrigation, Hydropower generation, Water supply etc. While Yeldari (R3) project releases water mainly for the purpose of hydropower generation through installed hydropower plant of capacity $15 \mathrm{MW}$ and Siddheshwar project (R4) release water for irrigation purpose.

\section{Model Development}

This study aims to maximize the two objective functions applied on multi-reservoir system in a river sub-basin as follows.

1) Maximization of Release for Irrigation (RI)

$$
\max Z=\sum_{i} \sum_{t}(\mathrm{RI})_{i t} \forall i=1,2,3,4
$$

2) Maximization of Release for Hydro-Power generation (RP)

$$
\max Z=\sum_{i} \sum_{t}(\mathrm{RP})_{i t} \forall t=1,2,3, \cdots, 12
$$

As model is developed for four reservoirs on monthly operating basis, $i$ indicates the number of reservoirs and $t$ shows the number of monthly time steps. Above objective functions are subjected to various system constrains written as follows:

\subsection{Irrigation Release}

For all reservoirs the quantity of water release for irrigation purpose (RI) should be less than or equal to maximum irrigation demand $\left(I R R D_{\max }\right)$ for all time period and should be greater than or equal to the minimum irrigation demand $\left(I R R D_{\text {min }}\right)$. This irrigation release constraint is given by:

$$
\operatorname{IRRD}_{\text {min }}(i, t) \leq \mathrm{RI}(i, t) \leq \operatorname{IRRD}_{\text {max }}(i, t) \quad \forall i=1,2,3,4 ; \forall t=1,2,3, \cdots, 12
$$

\subsection{Turbine Capacity Constraints}

Constraints for turbine release are considered according to capacity of turbine installed in power house for hydro-power production. The maximum release for power production should be less than or equal to maximum capacity of flow through turbine for all month. Also, the hydro-power production for all months should be greater than or equal to the firm power requirement. Mathematically constraints are given by:

$$
\begin{aligned}
& \mathrm{RP}(i, t) \leq \mathrm{TC}(i) \quad \forall i=1,2,3,4 \\
& \mathrm{RP}(i, t) \geq \operatorname{FP}(i) \quad \forall t=1,2,3, \cdots, 12
\end{aligned}
$$

\subsection{Storage Capacity of Reservoir}

Reservoir storage (S) for all months should be less than or equal to the maximum reservoir storage capacity $\left(\mathrm{SC}_{\max }\right)$ of the reservoir and should be greater than or equal to Minimum Storage Capacity $\left(\mathrm{SC}_{\min }\right)$ of the reservoir. It can be given as:

$$
\mathrm{SC}_{\min }(i) \leq \mathrm{S}(i, t) \leq \mathrm{SC}_{\max }(i) \quad \forall i=1,2,3,4 ; \forall t=1,2,3, \cdots, 12
$$




\subsection{Environmental Flow Release}

Environmental flow is essential to preserve the river health and river ecosystem and must be considered in reservoir planning. Environmental flow (RE_EF) required for Godavari sub-basin is also considered. As per the CWC study report guidelines it is suggested that the quantity of minimum environmental flow should be taken as $0.5 \%$ of $75 \%$ dependable annual flow. The quantity of environmental flow is estimated as per the recommendations of CWC and constraint written as.

$$
\text { RE_EF }=0.5 \% \text { of } 75 \% \text { Dependable annual flow } \quad \forall t=1,2,3, \cdots, 12
$$

\subsection{Constraint of Hydrologic Continuity}

Hydrologic continuity constraints deal with release from turbine (RP), release for irrigation purpose (RI), a constant value for drinking water supply release (RWS) and release of environmental flow (RE_EF) is taken, storage of reservoir (SC), inflows (IN), different Losses from the reservoirs like loss due to evaporation for all months. The individual hydrologic continuity constraint for each reservoir is written as:

- Jayakwadi Stage-I (R1)

$$
\begin{aligned}
\left(1+a_{t}(1, t)\right) \mathrm{S}(1, t+1)= & \left(1-a_{t}(1, t)\right) \mathrm{S}(1, t)+\operatorname{IN}(1, t)-\operatorname{RI}(1, t)-\operatorname{RP}(1, t) \\
& -\operatorname{OVF}(1, t)-\operatorname{RWS}(1, t)-\operatorname{FCR}(1, t)+\alpha_{1} \operatorname{RP}(1, t) \\
& -\operatorname{RE} \_\operatorname{EF}(1, t)-A_{0} e_{t}(1, t) \\
\forall t= & 1,2,3, \cdots, 12
\end{aligned}
$$

- Jayakwadi Stage-II (R2)

$$
\begin{aligned}
\left(1+a_{t}(2, t)\right) \mathrm{S}(2, t+1)= & \left(1-a_{t}(2, t)\right) \mathrm{S}(2, t)+\operatorname{IN}(2, t)+\alpha_{2} \operatorname{FCR}(1, t) \\
& -\operatorname{RI}(2, t)-\operatorname{RP}(2, t)-\operatorname{OVF}(2, t)-\operatorname{RWS}(2, t) \\
& -\operatorname{RE} \_\mathrm{EF}(2, t)-A_{0} e_{t}(2, t) \\
\forall t= & 1,2,3, \cdots, 12
\end{aligned}
$$

- Yeldari (R3)

$$
\begin{aligned}
\left(1+a_{t}(3, t)\right) \mathrm{S}(3, t+1)= & \left(1-a_{t}(3, t)\right) \mathrm{S}(3, t)+\mathrm{IN}(3, t)-\operatorname{RP}(3, t)-\mathrm{OVF}(3, t) \\
& -\operatorname{RWS}(3, t)-\operatorname{RE} \_\mathrm{EF}(3, t)-A_{0} e_{t}(3, t) \\
\forall t= & 1,2,3, \cdots, 12
\end{aligned}
$$

- Siddheshwar (R4)

$$
\begin{aligned}
\left(1+a_{t}(4, t)\right) \mathrm{S}(4, t+1)= & \left(1-a_{t}(4, t)\right) \mathrm{S}(4, t)+\operatorname{IN}(4, t)+\alpha_{3} \operatorname{OVF}(3, t) \\
& +\alpha_{4} \operatorname{RP}(3, t)-\operatorname{RI}(4, t)-\operatorname{OVF}(4, t)-\operatorname{RWS}(4, t) \\
& -\operatorname{RE} \_\mathrm{EF}(4, t)-A_{0} e_{t}(4, t) \\
\forall t= & 1,2,3, \cdots, 12
\end{aligned}
$$

Jayakwadi Stage-I (R1) is a multi-purpose reservoir. Reservoir water is mainly used for irrigation of agricultural land in drought prone areas of Marathwada in the state. It supplies water for drinking and industrial use to nearby towns and villages and to municipalities and industrial areas in Aurangabad and Jalna dis- 
tricts. Another feature of this project is the bird sanctuary. Many species of birds from all over the country visit the Nathsagar Reservoir created by the dam. The abundance of waterfowl-loving swamps, algae, aquatic plants, small fish, insects and a wide variety of aquatic habitats attract domestic and exotic birds to reservoir. About 200 endemic and about 70 migratory birds of different species are found in the vicinity of this reservoir. Also, more than 50 species of fish are found in Jayakwadi reservoir. Total 183,322 Ha of command area receives irrigation supply from Jayakwadi Stage-I project through left and right bank canals. A pump storage type hydropower plant of $12 \mathrm{MW}$ capacity is also installed at Jayakwadi Stage-I project. Water released through power plant is stored in a pool at downstream and pumped back to reservoir. This volume of water is also considered in model with $10 \%$ of transition loss. Jayakwadi Stage-II (R2) is constructed on Sindaphana river which also receives water from Jayakwadi Stage-I reservoir through feeder canal. The feeder canal release (FCR) from Jayakwadi stage-I is added in model with $10 \%$ transition loss. A canal hydropower plant is also installed at Jayakwadi Stage-II project with capacity of $2.25 \mathrm{MW}$. Jayakwadi stage-II project irrigates around 93,800 $\mathrm{Ha}$, of area through right bank canal. Yeldari Reservoir (R3) is constructed on Purna river and generates hydropower through installed hydropower plant of capacity $15 \mathrm{MW}$ which is purely a hydropower project. Spillway overflow and turbine release from Yeldari project is taken into account for Siddheshwar Reservoir (R4) with 10\% transition loss. Siddheshwar reservoir is a pure irrigation project which irrigates command area of 57,988 Ha. Monthly inflow and maximum irrigation demand for all reservoirs are shown in Table 1.

Table 1. Inflow and maximum irrigation demand for reservoirs in million cubic meters.

\begin{tabular}{cccccccc}
\hline \multirow{2}{*}{ Month } & \multicolumn{2}{c}{$\begin{array}{c}\text { Jayakwadi Stage-I } \\
\text { Reservoir (R1) }\end{array}$} & \multicolumn{2}{c}{$\begin{array}{c}\text { Jayakwadi Stage-II } \\
\text { Reservoir (R2) }\end{array}$} & $\begin{array}{c}\text { Yeldari } \\
\text { Reservoir (R3) }\end{array}$ & $\begin{array}{c}\text { Siddheshwar } \\
\text { Reservoir (R4) }\end{array}$ \\
\cline { 2 - 10 } & Inflow & $\begin{array}{c}\text { Irrigation } \\
\text { Demand }\end{array}$ & Inflow & $\begin{array}{c}\text { Irrigation } \\
\text { Demand }\end{array}$ & Inflow & Inflow & $\begin{array}{c}\text { Irrigation } \\
\text { Demand }\end{array}$ \\
\hline Jun & 148.7620 & 18.55 & 20.98 & 7.12 & 72.83 & 7.71 & 33.1 \\
Jul & 408.2500 & 26.7 & 43.46 & 20.83 & 141.09 & 2.21 & 35.23 \\
Aug & 610.6600 & 25.43 & 96.88 & 37.64 & 200.36 & 11.97 & 35.23 \\
Sep & 600.0000 & 85.79 & 144.17 & 46.02 & 160.77 & 9.18 & 93.46 \\
Oct & 287.7500 & 267.86 & 75.52 & 132.01 & 123.1 & 1.29 & 77.6 \\
Nov & 196.4600 & 228.74 & 10.24 & 127.05 & 49.48 & 0.57 & 74.68 \\
Dec & 125.5300 & 210.88 & 4.27 & 89.43 & 35.58 & 0.89 & 65.14 \\
Jan & 37.6500 & 230.34 & 0.37 & 100.68 & 32.18 & 1 & 65.14 \\
Feb & 21.4620 & 85.23 & 0.37 & 30.02 & 24.23 & 0.39 & 35.5 \\
Mar & 19.5620 & 70.06 & 0.16 & 28.98 & 23.54 & 1 & 37.4 \\
Apr & 25.5000 & 85.49 & 0.12 & 35.58 & 13.15 & 0.4 & 30.5 \\
May & 46.5870 & 58.2 & 0.06 & 25.88 & 13.86 & 0.4 & 22.3 \\
\hline & & & & & & & \\
\hline
\end{tabular}




\section{Result and Discussion}

Optimal reservoir operation policies were developed for multi-objective multi-reservoir system by developing a multi-objective fuzzy linear programming model MOFLP to operate on monthly time interval. Developed MOFLP model is perform to maximize release for irrigation and maximize the release for hydropower production. Model is developed with Python programming. Latest version of Python 3 is used with an open-source linear programming package PuLP library. At first phase model was run by considering objective of maximization of irrigation release i.e. $(Z 1)$. As the priority is given for maximization of irrigation release, model generates best value of irrigation releases $(Z 1+)$ and worst value of releases for hydropower $(Z 2-)$. In second phase model run for objective of maximization of releases for hydropower i.e. $(Z 2)$. Here priority is given for maximization of hydropower release, model generates best value of irrigation releases $(Z 2+)$ and worst value of releases for hydropower $(Z 1-)$ as given in Table 2.

Table 2. Best and worst values of objective function.

\begin{tabular}{ccc}
\hline Objective Function (Maximization) & Best Value $Z+$ & Worst Value $Z-$ \\
\hline Releases for Irrigation $(Z 1)$ & $2108.02 \mathrm{Mm}^{3}$ & $1227.59 \mathrm{Mm}^{3}$ \\
Releases for Hydropower $(Z 2)$ & $1503.74 \mathrm{Mm}^{3}$ & $568.44 \mathrm{Mm}^{3}$ \\
\hline
\end{tabular}

Further linear membership functions are developed for fuzzification of objective functions.

Membership function of irrigation release

$$
\mu_{Z 1}(x)= \begin{cases}0 & \text { if } Z 1 \leq 1227.59 \\ \frac{Z 1-1227.59}{2108.02-1227.59} & \text { if } 1227.59 \leq Z 1 \leq 2108.02 \\ 1 & \text { if } Z 1 \geq 2108.02\end{cases}
$$

Membership function of hydropower release

$$
\mu_{Z 2}(x)= \begin{cases}0 & \text { if } Z 2 \leq 568.44 \\ \frac{Z 2-568.44}{1503.74-568.44} & \text { if } 568.44 \leq Z 2 \leq 1503.74 \\ 1 & \text { if } Z 2 \geq 1503.74\end{cases}
$$

From Equation (12) and (13) a new model is developed by introducing $\lambda$ as indicator for satisfaction level and model is solved for objective of maximization of satisfaction level indicator $(\lambda)$ subject to new constraints as per Equation (12) and (13). Because of newly added and all the original constrain model maximized $\lambda$ as objective and also maximize the both fuzzified objectives simultaneously. In developed model maximum value of $\lambda$ is obtained as 0.87 , which indicates the $87 \%$ of satisfaction is achieved in reservoir operation policy for both objectives with corresponding maximum total annual releases for irrigation of 1997.29 $\mathrm{Mm}^{3}$ and maximum total annual releases for hydropower production equal to 


\subsection{0 $\mathrm{Mm}^{3}$.}

Figure 2 shows results for reservoir R1, the total releases obtained for irrigation are $75.49 \%$ of maximum irrigation requirements. In case of reservoir $\mathrm{R} 2$ the total irrigation release obtained are $50 \%$ of maximum demand as shown in Figure 3. Figure 4 shows releases for reservoir R4, model satisfies $100 \%$ irrigation demand as R4 is purely irrigation project. Regarding hydropower generation in Figure 5 it is observed that, for reservoir R1 100\% releases required for hydropower generation are obtained. For reservoir R2 releases obtained for hydropower generation $59.07 \%$ of the maximum requirement as shown in Figure 6. Similarly in reservoir R3 total releases for power generation are the $80.17 \%$ of turbine capacity represented in Figure 7. CWC recommended releases for environmental flows are also made available from each reservoir. Total annual environmental flow releases maintained are $12.64 \mathrm{Mm}^{3}, 1.98 \mathrm{Mm}^{3}, 4.45 \mathrm{Mm}^{3}, 3.57 \mathrm{Mm}^{3}$ from reservoir R1, R2, R3, R4 respectively.

Irrigation Demand Vs Irrgation Release from Jayakwadi Stage-I Reservoir (R1)

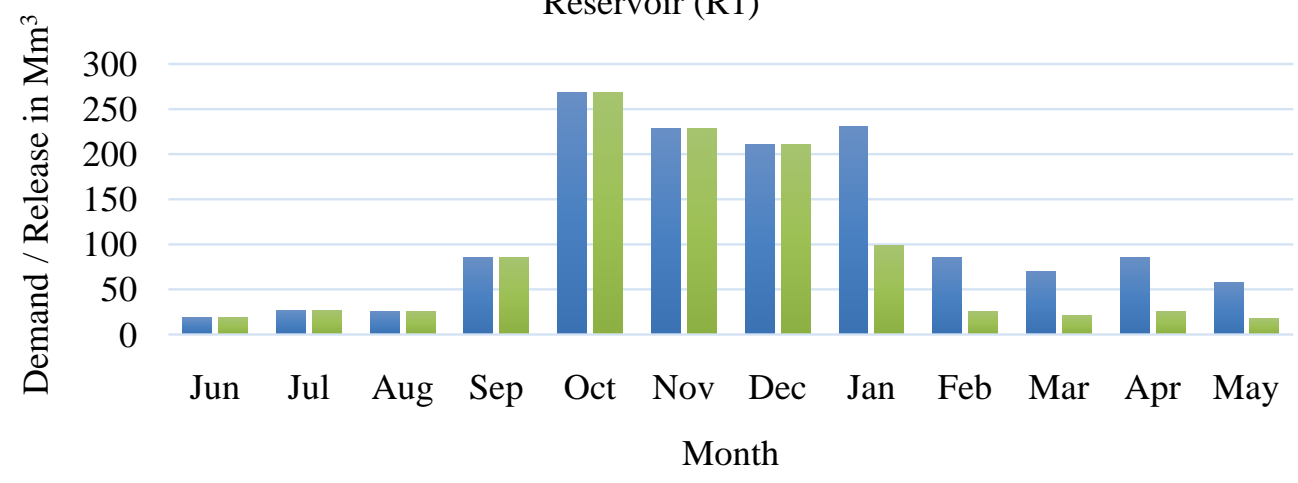

Maximum Irrigation Demand Irrigation Release

Figure 2. Jayakwadi Stage-I reservoir (R1).

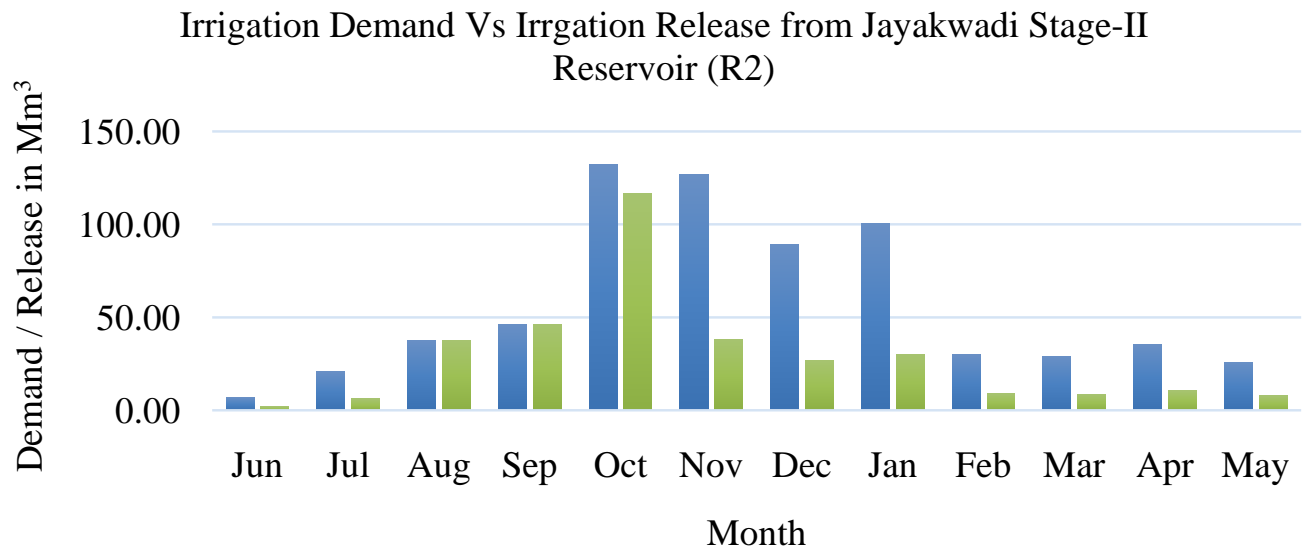

- Maximum Irrigation Demand $\quad$ Irrigation Release

Figure 3. Jayakwadi Stage-II reservoir (R2). 
Irrigation Demand Vs Irrgation Release from Siddheshwar Reservoir

(R4)

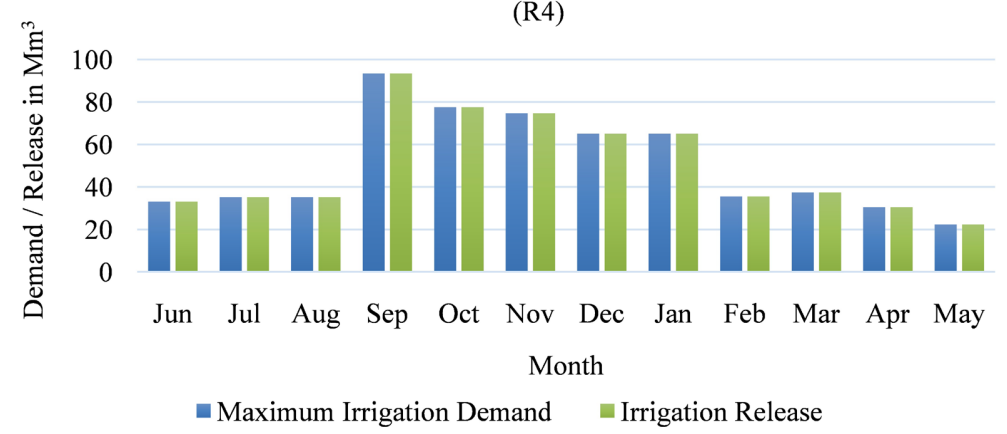

Figure 4. Siddheshwar reservoir (R4).

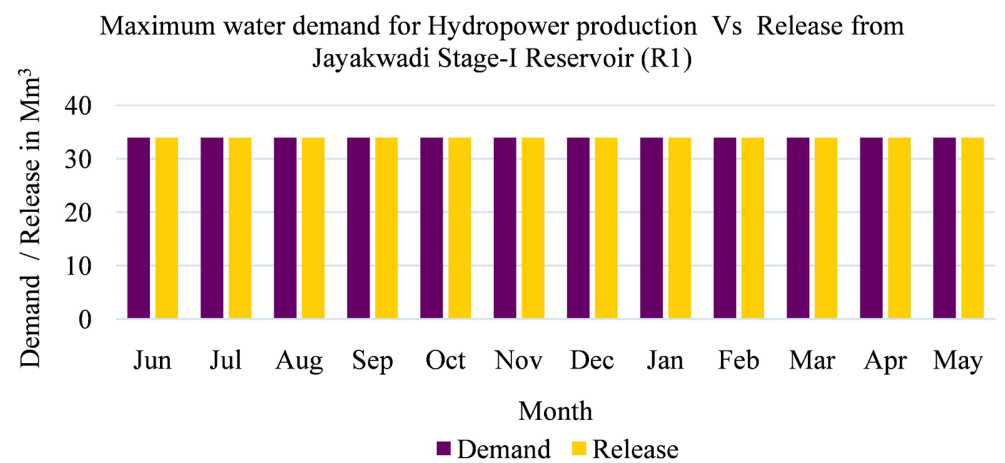

Figure 5. Jayakwadi Stage-I reservoir (R1).

Maximum water demand for Hydropower production Vs Release from Jayakwadi Stage-II Reservoir (R2)

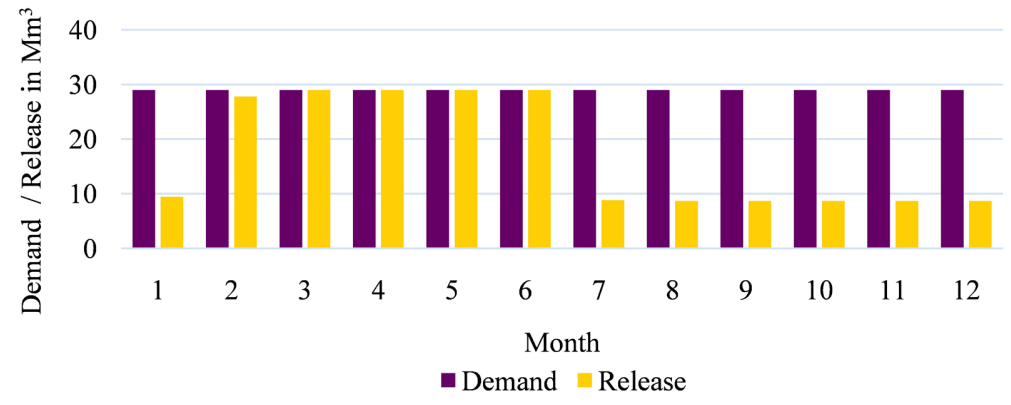

Figure 6. Jayakwadi Stage-II reservoir (R2).

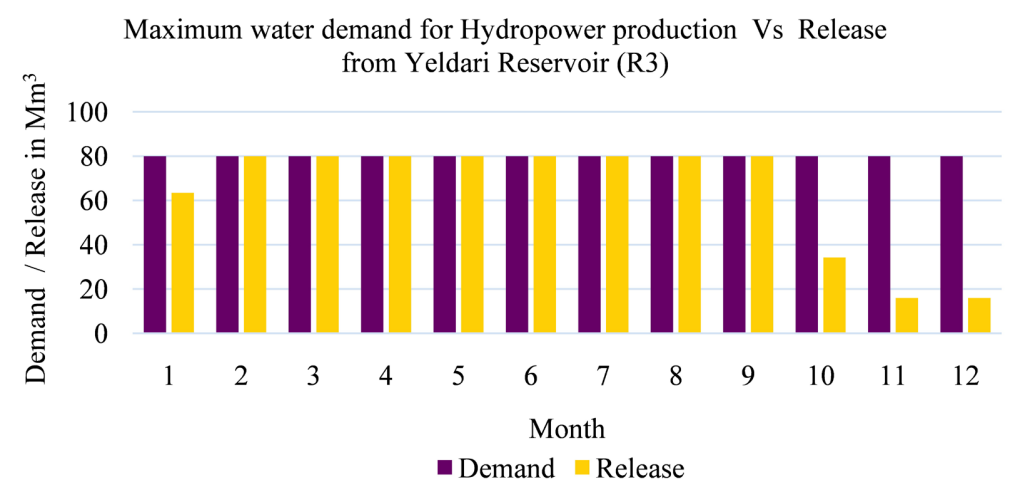

Figure 7. Yeldari reservoir (R3). 


\section{Conclusion}

The availability of water has always been a pressing issue for drought-hit Marathwada region of Maharashtra. This situation may worsen in the future, so it is imperative that proper planning of water use from Godavari basin and its reservoirs, which are socially and economically important for the region, is essential. Developed monthly operated model presents a holistic, sustainable approach for reservoir operation management in line with future water demands of humans as well as environment. Multi-objective fuzzy linear programming model achieves the $87 \%$ of level of satisfaction in releases for irrigation and hydropower generation simultaneously for all four reservoirs. The release of water as minimum environmental flow required for the aquatic environment as well as for various organisms dependent on river water has also been maintained uninterrupted through all four reservoirs.

\section{Acknowledgements}

The authors gratefully acknowledge the Command Area Development Authority, Aurangabad, Maharashtra State, India for providing necessary data for analysis.

\section{Conflicts of Interest}

The authors declare no conflicts of interest regarding the publication of this paper.

\section{References}

[1] Labadie, J.W. (2004) Optimal Operation of Multireservoir Systems: State-of-the-Art Review. Water Resources Planning and Management, 130, 93-111. https://doi.org/10.1061/(ASCE)0733-9496(2004)130:2(93)

[2] Wurbs, R.A. (1993) Reservoir-System Simulation and Optimization Models. Journal of Water Resources Planning and Management, 119, 455-472. https://doi.org/10.1061/(ASCE)0733-9496(1993)119:4(455)

[3] Kim, T., Heo, J.-H., Bae, D.-H. and Kim, J.-H. (2008) Single-Reservoir Operating Rules for a Year Using Multiobjective Genetic Algorithm. Journal of Hydro Informatics, 10, 163-179. https://doi.org/10.1016/j.jhydrol.2008.04.006

[4] Chen, H., Yang, L., Yang, Z.F. and Yu, S.W. (2012) Sustainable Reservoir Operations to Balance Upstream Human Needs and Downstream Lake Ecosystem Targets. Procedia Environmental Sciences, 13, 1444-1457. https://doi.org/10.1016/j.proenv.2012.01.136

[5] Mousavi, S.J., Ponnambalam, K. and Karray, F. (2005) Reservoir Operation Using a Dynamic Programming Fuzzy Rule-Based Approach. Water Resources Management, 19, 655-672. https://doi.org/10.1007/s11269-005-3275-3

[6] Nagesh Kumar, D., Baliarsingh, F. and Srinivasa Raju, K. (2010) Optimal Reservoir Operation for Flood Control Using Folded Dynamic Programming. Water Resources Management, 24, 1045-1064. https://doi.org/10.1007/s11269-009-9485-3

[7] Regulwar, D.G. and Raj, P. (2009) Multi Objective Multireservoir Optimization in Fuzzy Environment for River Sub Basin Development and Management. Journal of 
Water Resource and Protection, 1, 271-280.

https://doi.org/10.4236/jwarp.2009.14033

[8] Regulwar, D.G. and Kamodkar, R. (2010) Derivation of Multipurpose Single Reservoir Release Policies with Fuzzy Constraints. Journal of Water Resource and Protection, 2, 1030-1041. https://doi.org/10.4236/jwarp.2010.212123

[9] Yesmin, M. and Alim, M. (2021) Advanced Transformation Technique to Solve Multi-Objective Optimization Problems. American Journal of Operations Research, 11, 166-180. https://doi.org/10.4236/ajor.2021.113010

[10] Brisbane Declaration (2007) The Brisbane Declaration. 10th International River Symposium and International Environmental Flows Conference, Brisbane, 3-6 September 2007, Page No 1.

[11] Jain, S.K. and Kumar, P. (2014) Environmental Flows in India: Towards Sustainable Water Management. Hydrological Sciences Journal, 59, 751-769. https://doi.org/10.1080/02626667.2014.896996

[12] Lokgariwar, C., et al. (2014) Including Cultural Water Requirements in Environmental Flow Assessment: An Example from the Upper Ganga River, India. Water International, 39, 81-96. https://doi.org/10.1080/02508060.2013.863684

[13] Jain, S.K. (2020) Assessment and Implementation of Environmental Flows. Guest Editorial, Current Science, 118, 1011.

[14] CWC, Ministry of Water Resources, Government of India (2007) Report of Central Water Commission Working Group.

[15] Jalansh (2018) Monthly Newsletter of Central Water Commission, Issue No. 4. Water Systems Engineering Directorate Central Water Commission, New Delhi.

[16] (2017) Integrated State Water Plan for Godavari Basin in Maharashtra, Government of Maharashtra Water Resources Department Volume I. 